\title{
Local vs. Global Location of Firms and Industries
}

\author{
Miroslav N. Jovanović \\ UN Economic Commission for Europe
}

Does the Eagle Mount Up at Your Command, And Make Its Nest on High? Job 39:27

\begin{abstract}
Where economic activity will locate in the future is one of the most important questions in economics. Even though advances in technology have reduced the cost of transport, communication and information gathering and processing, hence curtailing the 'distance penalty', local proximity (clusters) of firms that produce similar, competing and/or related products together with supporting institutions still matter. Economies of scale, activity-specific backward and forward linkages (indivisible production), accumulated knowledge and skills, innovation, existence of sophisticated customers and a fall in transportation costs play relevant roles in the 'protection' of clusters and absolute locational advantages of certain locations. 'Global' competitiveness often depends on highly concentrated 'local' knowledge, capabilities and common tacit codes of behaviour which can be found in a geographical concentration (cluster) of firms.
\end{abstract}

- JEL Classifications: F15, F23, R12

- Key words: Global, Local, Cluster, Linkages, History, Lock-in.

\section{Introduction}

Any society and each market oriented firm must first refer to the problem of what, for whom, how and where to produce. One of the most important questions in economics is where economic activity will locate in the future. With this spatial

*Corresponding address: Doctor Miroslav N. Jovanovi ć UN ECE, Transport Division, Palais des Nations, 1211 Geneva 10, Switzerland, Tel.: +41-22-917-2493, Fax.: +41-22-917-0039, E-mail: miroslav.jovanovic@ unece.org

(C)2003-Center for International Economics, Sejong Institution, All Rights Reserved. 
distribution of economic activity in mind, the purpose of this article is to contribute to the debate about the 'local' versus the 'global' location of industries and firms. The approach employed is conceptual: the objective is to clarify and explain key tendencies, rather than to provide definite answers to the issue of the influence and consequences between local and global spatial distribution of production.

The spatial location of a firm is an issue only in a situation with market imperfections. Without market imperfections such as distance, transport costs and uneven distribution of natural resources (so that the location matters), there are no problems regarding deciding on the location of production. Without market failures firms may break up into units of any size and operate in any location with no cost disadvantage.

The structure of this article is as follows. Following this introduction, part 2 outlines principal theories regarding the location of firms. Part 3 discusses the controversial term of globalisation. Part 4 considers issues linked with the location of firms and industries in specific business areas such as clusters. Light is shed on the role of history, chances, accidents and wars in the selection of certain places for the location of production of goods and services. Discussion is supported with numerous examples. The conclusion is that 'global' competitiveness often depends on highly concentrated 'local' knowledge, capabilities and a common tacit code or codes of behaviour which can be found in a geographical concentration (cluster) of firms.

\section{Theories of Location}

The study of the location of production (spatial economics) has a long, although somehow meagre history (Krugman, 1998, p. 7). The problem was noted, for example, by Ohlin who wrote that 'the theory of international trade is nothing but internationale Standortslehre' (teaching about international location) (Ohlin, 1933, p. 589). In the same vein, Isard wrote that 'location can not be explained without at the same time accounting for trade and trade cannot be explained without the simultaneous determination of locations. ...trade and location are the two sides of the same coin' (Isard, 1956, p. 207).

Let us now turn to the principal theories about the location of a firm. Realising the arbitrary character of our classification and its limits, we shall first take a look into the issue of how and where firms and industries locate in space without paying attention to their origin, control and ownership. Later, we shall include the issue of ownership and control. 


\section{A. National Firm}

Adam Smith and David Ricardo referred to the geography of production and spatial economics in an indirect way. A country specialises in the production of a good for which it has an absolute advantage in production. Hence, according to Smith, an absolute advantage determines the geographical location of production. Ricardo's argument is similar, but in his model a country specialises in the production of goods for which it has a relative advantage in production.

In addition to these classical models, in the standard Heckscher-Ohlin model, the proportion of the national endowment of factors decides the location of production. A relatively abundant national factor of production (compared with other factors) determines what a country produces and exports. Conversely, countries import goods that require in the production factors that are scarce in the national economy. While considering cases of 'localisation' of industry in one or a few countries, Ohlin (1933, p. 133) simply argued that 'it must be shown that costs of production on the basis of existing factor prices are lower than in other countries: certain factors are cheaper here than abroad, which accounts for that condition'. This model elegantly assumes that there are no specific factors and that production functions are identical in all countries. As such, it does not give the answer to the whole issue, for it can not explain intra-industry trade.

While one may not dispute the importance of factor proportions for the location of production and some processing of primary resources, this approach can not explain the location of footloose industry. In their survey of trade theory, Leamer and Levinsohn (1995, p. 1363) stated that 'one rather awkward assumption that cries out for change is that of equal numbers of commodities and factors. After all, we really don't know how to count either.' Recent empirical research found 'that the degree of production indeterminacy is greatest when trade barriers and trade costs are relatively low' (Bernstein and Weinstein, 2002, p. 73). The existence of more goods than factors, trade costs and differences in technology present the principal obstacles for predicting the location of production and specialisation.

In addition, the Heckscher-Ohlin model does not consider market structure, demand conditions and trade costs. The Heckscher-Ohlin theory is inadequate in providing the reason for the location of an industry in regions with high mobility of factors (such as the United States $[U S]$ ) or in countries with broadly similar endowment of factors (France and Germany). ${ }^{1}$ A common feature in standard trade theory is that it considers states, while it utterly ignores the firm or the 
distribution of economic activity within a country. This gap is bridged by spatial economics.

A common starting point in spatial theory is the land rent and land use model by von Thünen (1826). This model is primarily concerned with the location of agricultural production. The model assumes a given isolated city (one consuming centre) and surrounding agricultural hinterland, as well as homogeneous land surface. Land rents are highest in the city. From there, they steadily decline to zero at the outermost limit of cultivation. Using the above assumptions the model explains the kind of crop that would be grown at places with different distances from the market. In other words, farmers decide on the type of production by taking into account land rent and cost of transportation. As transport costs and yields differ among crops, the result is the spontaneous development of concentric circles of production around the city. Land is allocated among different crops in a (optimal) way that minimises the production and transport costs of different crops. Von Thünen's model is based on careful study of farming practices in northern Germany in the early $19^{\text {th }}$ century. Such distribution of farmland is less obvious in the modern more intricate world, but there are certain remnants around large urban centres such as dairy production and gardening. This early model, however, does not consider the role played by economies of scale.

The problem in the von Thünen model is to find which good to produce in the given location. In the model of optimal plant site by Weber (1909) the branch of industry is given, so the problem is to find the spatial location for production. Weber's model takes the geographical location of markets, raw materials and population as given and assumes that there can be only one location for production. The objective of an individual producer is to minimise the combined costs of production and delivery. When the production costs are independent of location, the locational problem relates to the minimisation of transport costs for inputs and

\footnotetext{
${ }^{1}$ Since a large part of trade among developed countries has an intra-industry character, this may lead to the conclusion that the Heckscher-Ohlin (factor proportions) theory of trade is not valid. Intra-industry trade (a relatively large share of total trade among the developed countries) is not based on differences in factor endowments among countries. Countries tend to specialise and export goods that are demanded by the majority of domestic consumers. It is this demand that induces production, rather than domestic factor endowment. Countries have a competitive edge in the production of these goods and thus gain an advantage in foreign markets, while they import goods demanded by a minority of the home population (Linder, 1961). The US, Japan and Germany had the greatest comparative advantage in goods for which their home market is relatively big. These are standardised goods for mass consumption.

${ }^{2}$ In the case of one market and two deposits of resources, the optimal firm location would fall inside the triangle area which links these three different spots.
} 
output. $^{2}$ This is the key condition in the decision-making process about the location of a firm. However, when there are key resources that are used on a large scale in certain industries and that are highly localised, this may affect the location of manufacturing industry. These industries would be attracted to resource sites. Hence, this case is 'out of step' with spatial uniformity and the underlying principle of central place location for some, but not for all kinds of manufacturing. The problem with this approach to the location of new firms is, however, that the initial, static locational needs of a firm may change over time as the firm, industry, technology, consumers' needs and tastes or markets change and develop. There is also the possibility of a historical accident which can be coupled with the economies of scale, lock-in effect and agglomeration.

Geographical remoteness can be a handy scapegoat to some who may use it to explain why peripheral regions are marginalised in economic and certain social terms. It is, however, a shallow justification for many industries. Innovations in transport and communication technologies have made these costs rarely the most important determinant for the location of business. Hence, a peripheral location is not an undefeatable obstacle for a number of businesses as demonstrated in the case of countries such as Japan, Australia, New Zealand, Finland or Ireland. Moses (1958) extended Weber's work and integrated location theory with the theory of production. This allowed investigation of the relation between substitution of inputs and geographical location of a firm.

Christaller (1933) wanted to clarify and explain the rationale for the number, size and spatial distribution of cities. The analysis is based on the idea of market threshold and transport distance. He put forward the idea that cities form a 'hierarchy of central places'. This hinges on the supposition that larger cities can sustain a wider variety of activities relative to smaller (low order) cities and villages. Such uneven distribution of production occurs because of economies of scale. In spite of its obvious value for the analysis of urban growth and distribution of services, this rigid application of the impact of market size neglects the consequences of unequal distribution of natural resources, progress in technology and negative externalities that come from agglomeration.

Developing further the central-place theory and the issue of how the economy fits into space, Lösch (1940) started with a useful, but most unrealistic assumption, that there is a perfectly even distribution of raw materials and population. An efficient pattern of central places would have the shape of nested hexagonal (honeycomb) market areas with no empty corners. ${ }^{3}$ This means that certain 
economic activities can be done only at a restricted number of locations. It was subsequently demonstrated that there is a wide range of geographical configurations of firms. The spatial arrangements that can satisfy the equilibrium condition include squares, rectangles and regular and irregular hexagons (Eaton and Lipsey, 1976, p. 91). Even though based on unrealistic assumptions, the model of central places need not be disregarded. A coherent general equilibrium model found certain justification for the central-place theory (Krugman, 1993, p. 298).

The theory of central places points to the factors that need to be examined during the decision making process about the location of an industry or a firm. These factors are sources of supply, intersections of traffic routes and the centre of gravity. ${ }^{4}$ In order to reduce inaccuracy in such a 'technical' process (suitable for the centrally planned system) one needs to consider additional elements of a market based economy. They include actions of other functionally related firms, competitors, consumers and government policies.

The classical German location theory dealt with the locational decisions of firms which are in essence reduced to two issues: homogeneous distribution of natural resources over a flat space and optimum cost of transport. This literature dwelt on the geometrical shape of market areas in an idealised landscape or with the optimal production site given resources and markets. It ignored the crucial issue of market structure and competition. This was 'doing things in the wrong order, worrying about the details of a secondary problem before making progress in the main issue' (Krugman, 1992, p. 5). Organisational issues such as institutional reality and policies were put aside. Institution-free theoretical models avoid the problem of the impact of various policies on the location or reallocation of firms and industries.

Perroux $(1950 ; 1955 ; 1961)$ introduced a predominantly intuitive concept of 'growth poles' in spatial economics. The idea was discussed in the context of controversy between balanced and unbalanced regional growth during the 1950s. Geographical agglomeration, significant production linkages (with the key industry) and strong human contacts are necessary for the growth of a pole. A firm

${ }^{3}$ If one imagines a geometrically even distribution of centres across a flat and homogeneous surface and the corresponding circles (representing ranges of goods) around them, then if one wants to cover all the space with circles, there would be an overlap between the two adjoining circles. If one draws a straight line between the points where the two adjoining circles intersect, one would get a hexagonal market space of identical size around each centre without empty corners, as consumers would purchase goods from cheapest (nearest) producer.

${ }^{4}$ Paris and Madrid have a relatively central geographical location in France and Spain, respectively. 
is located in a space consisting of poles. Each pole has both centrifugal and centripetal forces. Hence, each pole has its zone of influence (it attracts and repulses firms) and interacts with other poles. If, however, a certain pole does not have a degree of flexibility and adaptability to new technologies and changes in the market, it will stagnate and decline. For instance, France selected eight urban areas and bolstered their growth during the 1960s in the expectation that such policy would counteract the growth of Paris. Hence, the policy of geographical concentration of investments was diluted over time as it was coupled with political snags. Many other national 'areas' exerted pressure to be included in the select group of geographical poles for special treatment. The evaluation of the policy of geographical growth poles is coupled with difficulties, as it was not vigorously implemented in practice.

Arthur (1989; 1990; 1994a and 1994b) argued that certain models of production geography give weight to differences in factor endowment, transport costs, rents and competition. In such cases, the pattern of production locations is an equilibrium outcome. Hence, in these models history does not matter. The locational system is settled and predictable (Arthur, 1994a, pp. 49-0). However, if one includes consideration of increasing returns and multiple equilibria, the new model has four properties that cause serious difficulties in analysis and policymaking. These features are (Arthur, 1989, pp. 116-7):

- Non predictability: ex ante knowledge of firms' preferences and potentials of technologies may not be sufficient to predict the 'market outcome'.

- Potential inefficiency: increasing returns ( $i$-activities) may uplift the development of technology with inferior long run aptitude. ${ }^{5}$

\footnotetext{
${ }^{5}$ Positive feedback economics may also find parallels in non-linear physics. For example, ferromagnetic materials consist of mutually reinforcing elements. Small perturbations, at critical times, influence which outcome is selected (bifurcation point), and the chosen outcome may have higher energy (that is, be less favourable) than other possible end states (Arthur, 1990, p. 99).

${ }^{6}$ The American nuclear industry is dominated by light-water reactors as a consequence of the adoption of such a reactor to propel the first nuclear submarine in 1954. Engineering literature asserts, however, that gas-cooled reactors would have been a superior choice (Arthur, 1989, p. 126). If the claim that Betamax is a technically superior system for video recorders than the VHS which won the market race, then the market choice did not represent the best outcome. Similar arguments could be used for the triumph of DOS over Macintosh during the mid-1980s. In addition, the 'qwerty' arrangement for typewriter keyboards was designed in the 19th century. Its name refers to the first six top line letters. Even though it has repeatedly been shown that this distribution of letters was sub-optimal, the 'qwerty' system is still the standard for keyboards.
} 
- Inflexibility: once an outcome such as a dominant technology begins to surface it turns out to be more 'locked in' and persists for a long period of time. ${ }^{6}$

- Non-ergodicity: ${ }^{7}$ small, unpredictable, random and arbitrary events (chances and accidents), path dependence and economies of scale in a non-ergodic system may set in motion mutations in economic structures and irrerersibility that decide the final outcome as they are neither normalised, nor averag-ed away, nor forgotten by the dynamics of the system.

The probability of the location of an industry resulting from an historical accident is shown in highly stylised, graphical form in Figure 1 (Arthur, 1994b: 107-109). If the distribution of potential locations of an industry is concave (Figure 1a), with a single minimum and a corresponding single outcome, the location is not influenced by historical chance. This type of distribution is exemplified by the mining and steel-making industries, which are normally located close to their source of raw materials. If, however, the distribution is convex (Figure 1b), with two minima, then there are two potential outcomes, each resulting in a different location which may depend on the historical chance. Hence, multiple equilibria make policy analysis conceptually difficult. This type of distribution is exemplified by corner shops, bakeries and petrol stations. However, firms in most industries need to be close to each other (i.e. they tend to agglomerate and create towns and cities), not only to be close to common suppliers of inputs, but also to foster competition and to facilitate exchange of information, which can be hampered if firms are spatially dispersed.

Figure 1. Concave (a) and convex (b) distributions of potential industry locations.

(a)

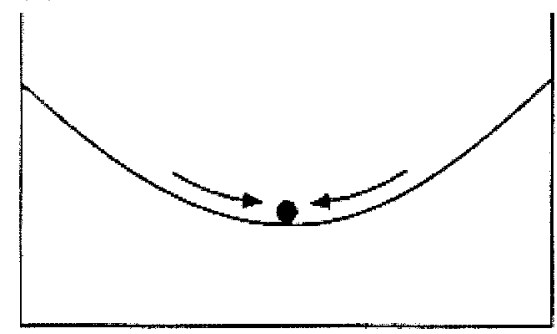

Historical chance irrelevant (b)

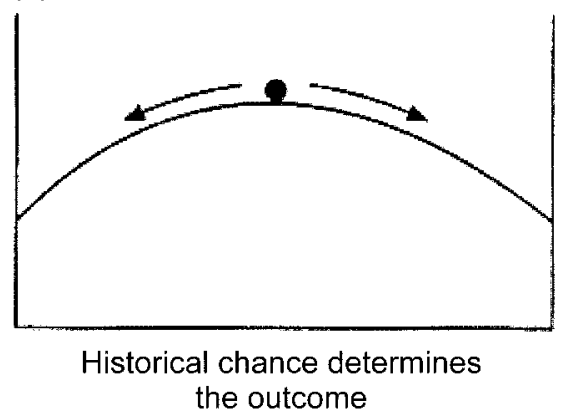

\footnotetext{
${ }^{7}$ An ergodic system (a pendulum) returns at the end to its original state no matter what the disturbances between the starting and ending points in time.
} 
If agglomeration forces based on increasing returns are unbounded, then a single geographical location monopolises the industry. Which region is selected depends on its geographical attractiveness and historical accident of firm entry, in particular early preferences of first entrants. If, however, agglomeration forces that come from increasing returns are bounded, then various regions may share the industry as if agglomeration economies were absent (Arthur, 1990a, p. 249). Locations with a large number of firms cast an 'agglomeration shadow' in which little or no settlement takes place. This causes separation of an industry. With bounded agglomeration economies, neighbouring locations cannot share the industry, but sufficiently separated regions can. Bounded agglomeration econo-mies caused separation and dispersion. Again, "which locations gain the industry and which become orphaned is a matter of historical accident' (Arthur, 1990a, p. 247).

According to the analysis of spatial economics by Fujita, Krugman and Venables (1999, p. 131), cities exist because firms locate at a cusp in the market potential function made by a concentration of other firms. Cities form because growing and spreading agricultural population makes it beneficial for producers to create new cities. The size of the cities differ (there is a hierarchy) because of differences in industrial externalities and transport costs. Finally, natural advantages (i.e., the existence of harbours) help as they create natural cusps in market potential. In addition and according to Arthur (1994b, p. 109), the observed pattern of cities can not be explained only by economic determinants without considering chance events. They are also the result of the places where immigrants with certain skills landed, where the politicians decided to build railways and canals or where trains stopped for the night.

Why are cities (clusters) of different sizes ? Henderson (1974) argued that there is a trade-off between economies of agglomeration of industries specific to that city and general diseconomies (negative externalities) such as costs related to commuting and high rents which (apart from pollution) do not depend on the structure of the local industry. The optimum city size depends on the maximum welfare of participants in the economy. It does not make much sense to put industries without spillovers (steel production and publishing) in the same city. Cities need to be specialised in one or a few industries with related external economies. These external economies, however, vary a great deal across industries. Because of strong links internal to the industry, a financial centre may do best if it includes virtually all financial institutions. This is not true for the textile or food industry. Hence, the optimal size of a city depends on its role (Fujita et al., 1999, 
p. 20).

\section{B. International Firm}

Ownership and control of the firm was neglected in the analysis by the implicit assumption that these do not matter or by the supposition that all assets are domestically owned. The presence of transnational corporations (TNCs) increases mobility of capital, expands availability of information and new products, it changes competition structure and alters substitution of labour for capital. A $T N C$ has different locational considerations than a comparable national firm engaged in the same type and scale of activity. A tendency is that strictly national firms expand where they already are, while TNCs enter where they think they may profit from access to the largest and growing market, favourable costs of labour, transport and/ or taxes and subsidies. TNCs have 'organisational capital', i.e. a common set of rules, practices, routines and values which help them overcome various barriers while operating in different geographical, social, legal and other environments.

There are at least seven basic theories that explain certain aspects of why firms engage in trans-border business activities and become TNCs. ${ }^{8}$ First, the motivation to control foreign firms may not come from the need to employ assets in a prudent way in foreign markets, but rather to remove competition from other enterprises. Hymer (1976) advocated such a market-power approach by TNCs. Reuber (1973, pp. 133-4) argued in a similar vein that long-term strategic factors for FDI include the desire to eliminate competitors from foreign markets, to be within a protected foreign market, to secure a low-cost source of supply and to lock the target country to a specific technology for a long time. Such a longer-term strategic view overshadows possible short-run variations in the profitability of FDI. The problem with this argument is that most TNCs (measured by their number) are small and medium sized. There were over 60,000 parent firms with over 820,000 foreign affiliates in 2000 (UNCTAD, 2001, p. 9). This shows that to become a TNC, a firm need not be a monopolist or an oligopolist at home and try to exercise that power abroad. If there is strong competition in the market for differentiated goods and services and an easy substitution is possible (perfumes, soaps, watches, clothing, vehicles, passenger air transport on certain lines, to mention just a few examples), then the market-power argument for the transnationalisation of business is weakened.

${ }^{8}$ In an early study, Weber (1909) offered two basic reasons why firms 'go to produce abroad'. The primary determinant is the achievement of lower labour and transport costs, while the secondary element is the benefit of large-scale production. 
Second, while the market-power model excludes potential rivals from competition, the internalisation theory holds that an arm's-length relation among individual firms is in some cases less efficient (e.g. trade in technology) than an intrafirm cooperative association. Profits may be maximised by means of efficient and friendly intra-firm trade in intermediaries that eliminates sometimes excessive transaction costs (middlemen, exchange-rate risk, infringement of intellectual property rights, bargaining costs) when the business is conducted through the market. In these circumstances a hierarchical organisation (an enterprise) may better reward parties in the longer term, as well as curb bargaining and incentives to cheat, than markets and external contractors. Payments of around 80 per cent of fees and royalties for technology 'take place between parent firms and their foreign affiliates' (UNCTAD, 1997, p. 20). This is an indication that TNCs play a key role in disseminating technology around the world (at least in the locations where they operate).

While Hymer conceives TNCs as vehicles for reaping monopoly profits and for the internalisation of pecuniary externalities, the internalisation model looks at $T N C s$ as a mode of business organisation that reduces transaction costs and internalises non-pecuniary externalities. This model of $F D I$ may be convincing in some cases, but it may not explain the structure and location of all FDI flows. In addition to the internalisation possibilities there ought to be ownership-specific and locational advantages for $F D I$.

Third, the eclectic paradigm (Dunning, 1988, pp. 42-5; 1999, pp. 1-3) explained the trans-border business activities of TNCs as a joint mix and interaction of three independent factors:

- In order to locate production abroad and be successful, a TNC must have or control internationally mobile income-generating ownership-specific $(\mathrm{O})$ advantages, assets or skills. These firm-specific advantages include tangible and intangible advantages such as better technology, brand name, access to wide markets, monopoly, competence of managers, etc. that are superior to the ones that are available to local firms (including other TNCs) in the potential target country.

- Locational (L) (non-mobile) advantages refer to the comparative or location-

${ }^{9}$ For example, governments may change over a certain period of time the availability, quality and cost of the domestic factors. The tools for such a policy would include training of labour and education of management, $\mathrm{R} \& \mathrm{D}$, science, transport and communication infrastructure and tax policies. 
specific advantages of the target country. They refer both to the geographical distribution of resources and to those created by the government. ${ }^{9}$

- There must be opportunities for the internalisation (I) of ownership-specific advantages (management and quality control, protection of property rights, avoidance of uncertainty of buyers, etc.). It should be in the interest of the firm to transfer these advantages abroad within its own organisation, rather than sell the right to use these advantages to other firms located in the country of intended production. Fixed exchange rates or a single international currency provide a degree of stability necessary for longer-term business planning with a high degree of confidence.

The eclectic paradigm claims that the exact mix of the $O L I$ factors facing each potential investor depends on the specific context. If a firm possesses/controls ownership-specific advantages, then it may use licensing in order to penetrate foreign markets. If it has both ownership-specific and internalisation advantages, such an enterprise may use exports as a means of entering foreign markets. Only when a firm is able to take simultaneous advantage of $O L I$ advantages, it will employ $F D I$ as a means of locating and operating in foreign markets. This model, however, does not apply to diversified and vertically integrated TNCs (Caves, 1996, p. 5).

Fourth, the product-cycle model reasons that mature (and, perhaps, environmentally unsound) lines of production of goods (there is no explicit reference to services) are being passed on to developing countries (Posner, 1961; Vernon, 1966). Such spatial reallocation of production depends a lot on low factor costs. This argument can not pass the test of recent developments as the major explanation for the location of business abroad. There is a heavy concentration of FDI in developed countries ( 88 per cent of the world stock in 2000), while the majority of developing countries are relatively neglected in FDI flows. In addition, countries start investing abroad at a much earlier stage of their development than before. The newly industrialised countries and many other developing countries are investing abroad. In many cases these investments are in the developed world. Such developments may be prompted by the desire:

- to be present in developed countries' markets (closer to the customers)

- to be near the source and cluster of the major technological developments in manufacturing, distribution and management (to have a foreign 'listening and learning post') 
- to participate in R\&D programmes

- to avoiding dangers of protectionism in target countries

- to win public contracts

- to exploit the strength of the host country's domestic currency

Fifth, is the follow my leader thesis. Oligopolists are risk minimisers. They like to protect their own market position and avoid destructive competition. Therefore, they typically try to minimise risk and follow each other into new (foreign) markets (Knickerboker, 1973, p. 100). A study of timing of FDI by the U.S. TNCs in manufacturing seems to support this proposition. The Japanese TNCs in the carmaking and consumer electronic industries were 'following their domestic leader' and located their manufacturing facilities in the European Union $(E U)$ and U.S. during the 1980s and 1990s. In addition, the mergers and acquisitions 'mania' of the 1990s in the $E U$ and U.S. shows how assets-seeking by one TNC may be followed by others.

Sixth, the competitive international industry model for the location of business abroad refers to oligopolistic competition and rivalry within the same industry. This is basically exchange of threats (tit for tat strategy) to business moves by foreign rivals (Graham, 1978). Large firms keep an eye on the actions of their rivals, i.e., they act strategically (pay attention to the likely reaction of their competitors to their own actions). What Texaco does in Europe, Shell will (try to) do in the U.S. Competition is not 'cut-throat', but rather 'stable' among several oligopolies. Other examples of this rivalistic trend include FDI in the manufacturing of cars and tires or the supply of services such as hotels and advertising. Small and medium-sized enterprises (SMEs) such as gas stations in the middle of nowhere may in their business, act independently. However, SMEs in a cluster keep a vigilant eye on the actions of their competitors.

Seventh, is the diversification of portfolios model of foreign investment (Brainard and Tobin, 1992). This approach considers uncertainty. Fluctuations in the rates of return on capital invested in various countries introduce an element of risk. This inconvenience may be reduced by a diversification of portfolios.

In addition to the seven basic theories on why firms locate abroad, two other dimensions are relevant for coming to grips with the issue. Kravis and Lipsey (1982, p. 222) argued that the location of foreign affiliates of TNCs is decided on the basis of cost minimisation. However, the intensity of this determinant varies from industry to industry. While Yamawaki (1993, pp. 19-20) did not dispute the 
importance of a relative difference in factor costs, the availability of technology in the target country is an additional and equally important factor for the location of Japanese $F D I$ in the $E U$. A Japanese $T N C$ from a certain industry decided to locate in the $E U$ country which has a certain advantage over other $E U$ countries in the same industry. Britain is preferred by the Japanese TNCs for the location of production of cars and electic/electronic equipment, Germany for precision instruments and machinery, Belgium for stone, glass and clay products, while TNCs in chemicals prefer Germany, Netherlands, Spain and France (Yamawaki, 1993).

No single theory can provide a completely satisfactory answer to the issue of trans-border investment activities of firms. However, if taken together, these theories may provide useful elements for the understanding of the issue.

\section{Globalisation}

Liberalisation in the national and international economy is a policy choice of governments, primarily in the developed world. It is linked with privatisation and downsizing of the activities of the public sector and the expansion of the activities of the private sector. Globalisation of the economy and production is a fact. It is the outcome of the behaviour of firms (TNCs), their organisation, changing technology in production and distribution, control and finance, as well as economies of scale. In part, it is also the consequence of a change in the behaviour of consumers (declining loyalty to national producers and certain national products) ${ }^{10}$ and liberalisation of national and international economies for trade, production and finance.

As a process primarily driven by actions of TNCs (power is shifted from states to firms) ${ }^{11}$ globalisation lacks two important components: transparency and accountability. ${ }^{12}$ This process deals with the change in the geography of (integrated international) production and consumption as it reduces the importance of

\footnotetext{
${ }^{10}$ One should not accord an absolute value to the decline of consumer loyalty to local brands. Regional, rather than 'global' strategies in certain food and health-care products may offer a superior business outcome. However, there was a certain 'global success' by, for example, Coca-Cola, which succeeded in replacing a part of the consumption of milk and healthy natural fruit juices for an artificial and sweet liquid that has a questionable impact on health and weight.

${ }^{11}$ Now governments court firms (TNCs) to come and locate within the confines of their control. Critics say that the protection of the vulnerable in society or safeguarding of the environment is weakened, even that it is left at the mercy of big businesses. This may be the case in certain lines of production.

${ }^{12}$ The same holds for the increase in the influence of special influence groups such as non-governmental organisations. Do these unelected groups of people with sometimes questionable accountability represent a risky shift of power towards special vested interests? Or do they represent a move towards the new 'civil society' (does anyone know the definition of this type of society)?
} 
proximity to inputs or markets. It widens boundaries and deepens space for the geographical location of production and consumption because of the declining costs of getting goods and services to the market. A rapid expansion of FDI is the key component of this process. Capital market liberalisation and increased capital mobility have radically reduced the influence of governments in the monetary sphere. However, governments have gained increased control in other areas. For example, computers and information technology have greatly increased potential for data collection and processing, and consequently control over firms and citizens which is relevant for tax and other purposes.

Regionalisation is increasing in importance in the world economy. This was exemplified in the inability of 135 member countries of the World Trade Organisation (WTO) to agree even on the agenda for the 'Millennium Round' of global trade negotiations that took place on 30 November 1999 in Seattle. Well-organised, vociferous and strong world-wide protests by environmentalists, farmers, enemies of genetically modified food and big business, labour unions and animal rights activists just added to the problems of that meeting and many others that followed. Therefore, the creation of integrated global economic policies is likely to be a very hard task for quite some time to come. It seems that the regional approach to economic problems will call the tune at least in the medium term.

The rapid international expansion of TNCs made them the most visible feature of globalisation. Being foreign, making sometimes visible and highly publicised mistakes and being often big, TNCs are easy targets for non-governmental organisations (NGOs) which can run successful campaigns to disgrace a mighty TNC. NGOs increased public awareness and pushed through agreements on the control of 'greenhouse gases' in the United Nations Conference on Environment and Development, the 'Earth Summit' in Rio de Janeiro in 1992. They also helped in torpedoing the Multilateral Agreement on Investment in 1998 and made a big ado in Seattle in 1999 (and many other subsequent meetings), which contributed to the failure to start a new WTO round of global trade negotiations before the meeting in Doha in November 2001. No matter how justified the reasons for the campaign, these 'civil society' protestors against global capitalism demonstrated that the tide of globalisation could be checked and even turned back.

The anti-globalisation campaigners have shown that governments are not powerless. The authorities can just as easily dismantle old trade and investment barriers, as they can introduce new ones. New technology, in particular the Internet, telecommunications, computing and data processing can offer some of 
the greatest economic opportunities ever for increasing living standards in all countries. Governments and the elite in all countries (due to incompetence or indifference) have failed to explain this. However, the process needs to be coupled with balanced policies both in the rich and poor world. Even though global economic integration may be the best end point for the future of the world economy for the proponents of globalisation, it is more likely that other outcomes may be chosen for the time to come. Globalisation may be favourable for economic efficiency, but it can be harmful for social goals.

Apart from a partial integration of international production, globalisation brings risks and disruptions. Volatile capital flows, speculative attacks on currencies, financial crises and unpredictable reallocation of jobs are obvious examples of increased economic and social vulnerability of many countries, in particular in the developing world. To wrap up the issue, Henry Kissinger labelled globalisation as 'another name for the dominant role of the United States'. ${ }^{13}$

The vogue term 'globalisation' has not yet been well or clearly defined. Hence, this fuzzy, but powerful metaphor is overused; often abused and very often misleading. Basically, it refers to the choices and strategies, as well as the shape, extent, direction and significance of activities of TNCs. Globalisation is also linked with and invigorated by new technologies in communications and information processing. Another incentive to the process of globalisation can be found in changes in economic strategy in many countries as outward-looking economic models replace inward-looking and TNC-hostile economic policy approaches. ${ }^{14}$

The Internet symbolizes the borderlessness brought about by globalisation. Physical presence in a specific location is not necessary. In cyberspace, the users are 'everywhere and nowhere' at once. However, one does not need to give an absolute value to globalisation. In spite of this process, localisation and clusters still matter. Firms that went furthest in 'globalisation' report that face-to-face contact is essential for the smooth organisation of business within the firm and marketing outside it.

The Internet is based on communication and data that are located in computers that exist in the real world. Initially, this parallel universe of pure data existed 'everywhere' freely in a lawless world. The Internet was breaking barriers and

\footnotetext{
${ }^{13}$ H. Kissinger, 'Globalisation: America's role for the millennium', The Irish Independent, 13 October 1999.

${ }^{14}$ 'Globalisation is no more than an (admittedly ugly) name for the process of integration across frontiers of liberalising market economies at a time of rapidly falling costs of transport and communications' (M. Wolf, The Financial Times, 3 October 2001, p. 15).
} 
eliminating physical distance. However, computers exist in an identifiable geographical space. If they can be located together with their users, then they are subject to law. Now governments are increasing their control over the cyberspace. For example, France prohibited the sale of Nazi memorabilia on the Internet, Iran banned access to immoral or anti-Iranian information, while South Korea prohibited access to gambling websites. Hence, borders are being created in the Internet. Even though the economic impact of geographical distance is being reduced, the local economic geography is keeping its strength.

The imposition of 'global' standards may have its justification for relatively new and standardised goods and services such as copiers, fax machines, computers or mobile phones, otherwise communication and exchange of information might be difficult and costly. However, the imposition of such standards for traditional goods (e.g., food) with the exception of health and the environment may not be easily justified. If tastes for certain types of food are strongly locally specific (even the thickness of pizzas throughout Italy differs) why should one favour or impose global Pizza Hut type standards?

John Gray of the London School of Economics said that faith in globalisation melted down and that 'led by the United States, the world's richest states have acted on the assumption that people everywhere want to live as they do. As a result, they failed to recognise the deadly mixture of emotions - cultural resentment, the sense of injustice and a genuine rejection of western modernity - that lies behind the attacks on New York and Washington... The ideal of a universal civilisation is a recipe for unending conflict, and it is time it was given up' ${ }^{15}$

It is true that the greatest and matchless advantage of free markets and globalisation is that they give free choice to consumers. Economic interactions are voluntary, so consumers are free to chose, for example, between local and global goods and services. But, this is only on the surface. If global products are advertised by large TNCs aggressively, including campaigns that are often beyond the financial capacity of local competitors, then the 'free choice' by consumers may be restricted and the local producers (and certain dimensions of the local culture) may be damaged. Critics of such unchecked global capital movements say that global TNCs put 'profits before people'. When these TNCs 'start talking about how they will no longer put profits first, people (rightly) think they are lying'. ${ }^{16}$

Another cost of globalisation can be found in the examples of countries such as

\footnotetext{
${ }^{15}$ The Economist, 29 September 2001, p. 14. The reference here is to the attacks of 11 September 2001.

${ }^{16}$ The Economist, 'A survey of globalisation', 29 September 2001, p. 4.
} 
Mexico, Thailand, Indonesia, South Korea and Russia. Globalisation led these countries into financial crises in the second half of the 1990s. Without the exposure to global capital markets, the crises would not have developed as they did. The critics of this view argue that these countries would not have developed fast prior to crisis without such exposure. In any case, one ought to be fair and observe that certain 'global tendencies' were present in the past well before the current wave of globalisation. For example, there was (for whatever reason and means) a spread of certain European languages outside Europe; spread of Islam in Africa, Asia and Europe; or spread of Christianity in Latin America.

Trade and foreign investments (globalisation) are partners, not adversaries of social agendas, but they ought to be coupled with effective national and international institutions that ease adjustment problems (such as the polluter-pays principle). Globalisation may bring adjustment costs in the affected industries and la-bour markets, but this may be only transitory. The gradual opening up of markets in Japan during the 1970s, and later in south-east Asia during the 1980s and in China during the 1990s, demonstrates that as a country grows wealthier, it ceases to be competitive in the production of labour intensive goods. Such a country be-comes an importer of these goods and concentrates its production on higher value-added activities. Child labour and prostitution in poor countries would certainly decline if globalisation opened advanced countries' markets to the products made by their parents. Even though globalisation spreads symbols of highly dubious value such as Coca-Cola, McDonalds, MTV or chewing gum, ${ }^{17}$ it also spreads profound values such as the rights of women and children. However, it is unfor-tunate that this takes place at a much slower pace. A still unresolved problem is that under globalisation human rights may sometimes be more important than state sovereignty.

The debate about globalisation is often about jobs (social dimension). Supporters argue that it is beneficial and that it creates jobs, while critics argue the opposite and say that jobs migrate to trading partners and competitors. Certain segments of labour in all countries are suspicious of globalisation, as they no longer perceive the national government as a sure protector of their concerns against external threats. To counter these fears, the best long term policy response may be to advance possibilities for education and training, as technical progress has a strong bias against unskilled workers.

As far as firms are concerned, there is the search by efficiency-seeking enter-

\footnotetext{
${ }^{17}$ One thinks of the particular consequences of chewing gum for the cleanness of elevators and chairs.
} 
prises, particularly some TNCs, for seamless and wide international markets regarding trade and investment. On the one hand, the globalisation of economic activity is making national frontiers less divisive than was the case 'ever before'. ${ }^{18}$ Such worldwide economic integration and integrated international production of goods and services whereby competitors are in each other's backyard are made possible by the expansion of information and telecommunication technologies. ${ }^{19}$ That process is sometimes inverted, on the other hand, by the spread of regionalism pushed by relatively inefficient firms and governments that are driven by shortterm election interests, even though the conditions for a relatively successful integration process, such as that in western Europe, may be largely absent.

Regional integration (a second best solution) may be a promising form of supranational governance in areas where there is a strong case for coordination and harmonisation of national policies. Integration may resolve conflicts through positive cooperation within a cosy group but, if pushed to the limit, it may undermine multilateral (first best) trade and investment systems and fragment the world economy into conflicting regional blocs. Regionalism and globalisation/multilateralism need not necessarily conflict. If the regional blocs cooperate and if they adopt liberal external trade and investment policies, the outcome may be an overall welfare improvement. The pace of international trade liberalisation since the 1960s, as well as the extension of the General Agreement on Tariffs and Trade (GATT) into new areas such as services and agriculture, might have been much slower in the absence of challenges posed by the progress in integration in the $E U$. The debate should not be between regionalism and multilateralism, but rather between liberalism and interventionism (Blackhurst and Henderson, 1993, p. 412).

It is often forgotten that the spirit of 'globalisation' does not bring anything essentially new. The need is for more freedom for trade in goods and services and for capital mobility $(F D I)$. The economic role of national frontiers declines as national economies merge in a single 'global' unit. In a nutshell, the idea is to return to the essentials of the system that was prevailing before 1914. Re-glo-

\footnotetext{
${ }^{18}$ Increased international mobility of factors, increased international intra-firm transactions, expanding international cooperative arrangements between firms, the increasing importance of knowledge, as well as a reduction in transport and communication costs, support the process of globalisation and are constituent parts of it. In these circumstances, individual actions of national governments may not increase global welfare (pollution is an example) and certain supranational rules may be necessary in order to deliver more beneficial outcomes.

${ }^{19}$ Trade is relatively more concentrated within regions than FDI. This suggests that trade plays a more prominent role in intra-regional integration arrangements, while $F D I$ has a greater influence on global integration (UNCTAD, 1993, p. 7).
} 
balisation may be a more appropriate term.

An enlarged market is an important gain for efficiency-seeking firms in a small country. In a situation without integration, foreign countries can simply threaten a small country that they will introduce protectionist measures or sanctions against it (frequent threats by the U.S. to the Latin American and many other countries). Such a warning can seriously undermine the quality of all economic decisions in a small country. Integration enhances and secures market access for partner countries, as well as increases the potential for long-term competitiveness of a small country's goods and services. A common market may eliminate or harmonise national incentives to foreign TNCs to locate in partner countries (which were previously subject to countervailing duties). It also mitigates non-economic considerations, such as political pressures on third country investors to locate in a particular country.

Transnational corporations behave like other firms: they primarily follow the opportunities for making profit. Size and growth of the local market, including privileged access to international markets (instead of mere differences in the cost of labour), are the most prominent motivators for their trans-border business operations. In addition, in a situation where market liberalisation became a widely accepted policy choice, there is an increase in the importance of created assets (technology and ability to create it, business culture, capability to organise and control production and marketing, communications infrastructure, marketing networks) as determinants for FDI. Those are the reasons why 88 per cent of the activities of TNCs were located in developed market economies (measured by the stock of FDI in 2000) (UNCTAD, 2001). In spite of the talk about 'globalisation,' on average, a significant part of the output of affiliates is still sold on the local market. In this situation the developing countries and those with the economy in transition face very tough competition to attract TNCs.

Foreign investors will locate their activities in a country which offers the most favourable mix of cost of operation (production and marketing). FDI can be made simpler by regionalisation of the world economy and international economic integration. However, integration/regionalisation is only a supporting tool for the tendencies that bring globalisation of international business. Modern competitive firms are usually TNCs that 'globalise' their business in the search for seamless and widest markets. Therefore, an increasing share of domestic output even in the developed countries is under the control of foreign TNCs. The same holds for an increasing share of foreign output of domestic TNCs. Strong FDI relations may exist 
even though the countries or groups of countries are not formally integrated. Just take a look at the example of two-way FDI flows between the U.S. and the EU.

Large global inter-penetration of FDI reduces the chance that regional arrangements may turn into closed blocs. A 'hostage population' of TNCs may reduce the fear of retaliatory measures. Extensive FDI links between the U.S. and the $E U$ helped bring about the relaxation of potential conflict between the two partners regarding market access. The same is not yet true with Japan. There is the hope that Japan will mature as a foreign investor in the future and that potential conflicts with that country will be defused.

In order to avoid the weakening of the competitive position of $E U$ firms in global markets, the $E U$ may follow two courses, although there may be a strong appeal to employ a mix of the two. First, the $E U$ may increase protection of domestic firms against foreign TNCs through measures such as rules of origin, local content requirements and other trade related investment measures. Second, the $E U$ may open its domestic market and welcome foreign, in particular hightechnology, TNCs to locate their manufacturing operations in the $E U$. As widely argued, $E U$ firms in a sizeable part of its manufacturing industry are less efficient than their counterparts in the U.S. and Japan. Suppose that the $E U$ adopts a liberal economic policy; if the $E U$ firms adjust and withstand competition from foreign TNCs, they may, in relative terms, gain more from market liberalisation than their foreign competitors.

A caveat for developing countries is that sometimes they use tariff proceeds for investment purposes. If that is the case, a customs union may dry up an important part of domestic investments by lowering tariff revenue. In a situation with many market imperfections, the opportunities for gains and losses are numerous. Hence, long-term gains in growth that originate in international economic integration may offset this loss of tariff revenue. However, the question asked by the public choice theory is: are we sure that the government of the day in a developing country cares or can afford to care about long-term gain?

\section{Localisation}

\section{A. History, Chance, Accident and Clustering}

The Heckscher-Ohlin theory is inadequate in providing the reason for the location of an industry in regions with high mobility of factors $(U S)$ or in countries 
with broadly similar endowment of factors (France and Germany). Patterns of regional specialisation and location of firms and industries are often created by unpredictable, small, random and arbitrary events, as well as historical accidents (chances). Ohlin noted that 'Chance plays a significant part in determining the localisation of industry... A different distribution of inventions would have caused a different localisation' (Ohlin, 1933, p. 137). More recently Krugman wrote: 'I at least am convinced that there is a strong arbitrary, accidental component to international specialization; but not everyone agrees, and the limitations of the data make a decisive test difficult' (Krugman, 1992, p. 9). Chance and economies of scale are strong forces that influence the spatial location of firms.

Once a business is established at a specific geographical location, it is then 'locked in' through learning, circular and cumulative causation effects. In this sense '... history matters in a way that it does not in neo-classical theory...' (Eaton and Lipsey, 1997, p. xxv). Two questions are relevant here:

Are there inherent differences among locations that create predestination for certain activities?

How can a small historical accident, a chance (something that is beyond the prior knowledge of an investor), alter the economic fate of an industry, region or a country?

The non-linear probability theory can predict with some certitude the behaviour of systems subject to increasing returns. Suppose that balls of different colours are placed on a table. The probability that the next ball will be of a specific colour depends on the current proportion of colours. Increasing returns occur when a red ball is more likely to be added when there is already a high proportion of red balls (Arthur, 1990, p. 98). Equilibrium depends on the initial point and later arrivals. Hence, history as a series of (random) arrivals sets the final result. ${ }^{20}$

The national rate of growth of capital stock (without FDI and foreign loans) depends on home savings and investment. Suppose now that one region/country initially accumulates more capital than the other. In the following period both regions grow, but the one with more capital grows faster than the one with less capital. As manufacturing capital grows, the relative prices of manufacturing goods fall. After a certain period of time, there is a point at which the lagging region's industry can not compete internationally and it begins to shrink. Once this process begins the new theory of trade and strategic industrial policy suggests that

\footnotetext{
${ }^{20}$ Expectations can also influence the location of firms. The interested reader is invited to consult Krugman (1991) and Jovanovi ć (2001).
} 
nothing can stop agglomeration for a long time. Economies of scale may drive prices down in the capital-abundant region and at the same time the lagging region's manufacturing industry disappears. In this model, relatively small beginnings can have large and irreversible final consequences for the manufacturing structure of a country, its trade and the competitiveness of its output (Krugman, 1990, pp. 99-100).

The dynamics of capital accumulation makes the region that starts with a higher capital stock than the other regions, end up with a dominant industrial position. If this is reinforced with a learning process and cumulative causation (strong internal production links where extension of one activity increases the profitability of others), then the existing pattern of comparative advantage is reinforced over time. This process-dependent development adds new layers of firms and industries on the inherited production structure. If output is concentrated within a relatively small geographical area, firms can benefit from economies of scale and linkages (growth of one activity increases the profitability of other). If this area is close to a larger market, there are additional benefits in the form of lowered trade (including transport) costs. Hence, the current state of the economy determines its future shape.

Investment decisions and the trade policy of a country at the present time will have an impact on the shape of the national economy in the future. For example, at the end of the 19th century Argentina and Sweden were relatively comparable backward farming-based economies. At about the same time, Argentina invested in the education of lawyers and priests, while Sweden invested in the education of engineers. The impact of such choices coupled with other economic policies on the material standard of living of the two countries is obvious.

Once the structure of an economy becomes unsustainable, there are certain critical branching points (bifurcations) at which the qualitative behaviour of the economy changes. New production geography either evolves or is triggered. This history-dependent development can follow different paths; hence its unpredictability. A long period of stability is broken up by an event of change (equilibrium is punctuated). For example, nearly all big cities are ports. However, New York or Boston have for a long time ceased to be primarily harbour cities. One may find elsewhere examples of punctuated equilibrium. In biology, for instance, many species (crocodiles, crabs, turtles or monotreme animals) remain stagnant for a very long period of time. But there are crucial, relatively brief and unpredictable moments (bifurcations) when new species arrive and old ones disappear. These include changes in climate because of volcanic activity or the extinction of the 
dinosaurs caused by the fall of a meteor, which 64 million years ago also changed climate (the fall started fires which burned forests, while smoke covered the atmosphere which prevented the penetration of heat from the sun, hence a part of life on Earth was frozen).

More than a century ago Alfred Marshall spelled out the idea of 'backwardlooking dynamics' or external economies (in modern jargon). In his analysis, factors of production are moving towards those industries in which they earn the highest current rate of return. If there are several meaningful equilibria in which the returns are equalised, then the initial conditions determine the outcome. History matters, together with factor endowment, tastes and technology (Krugman, 1991, p. 653-4).

Marshall also described the concentration of specialised industries in particular localities in the following way. 'When an industry has once chosen a locality for itself, it is likely to stay there long: so great are the advantages which people following the same skilled trade get from near neighbourhood to one another. ... if one man starts a new idea it is taken up by others and combined with suggestions of their own; and thus becomes the source of yet more new ideas' (Marshall, 1890, p. 332). Contemporary jargon calls this process the externalities of innovation. ${ }^{21}$

Somehow similar 'first mover advantages' (to use the term from analysis of competition) may be found in biology as many bits and pieces of the past can be found long after their functions were lost. For example, 'embryonic birds and mammals still have gill arches, which have been useless for 400 million years. Why are the vestiges not eliminated by natural selection? The usual answer is that baupläne and the vestiges are developed early in the embryo and hence are most difficult to modify than features that develop later. The genetic programs controlling embryonic development were formed in the early days and have been frozen ever since' (Auyang, 1998, p. 195). A similar example can be found in the appendix in the human body. However, the question immediately comes to mind: why cannot newly created adaptive features also be frozen?

Positive feedback economics may also find parallels in non-linear physics. For example, ferromagnetic materials consist of mutually reinforcing elements. Small perturbations, at critical times, influence which outcome is selected (bifurcation), and the chosen outcome may have higher energy (that is, be less favourable) than other possible end states (Arthur, 1990, p. 99).

\footnotetext{
${ }^{21}$ Because of the availability of wood, Sweden developed a mighty pulp and paper industry. Strong links with suppliers contributed to the replication of that success in the machinery that handles wood, pulp, and the making and drying paper.
} 
One of the chief causes of the localisation of industries can be found in the physical conditions of the area, for example, the production of metals located either near mines or close to sources of cheap energy. First-rate grit (for grindstones) was found near Sheffield, England, therefore it became the place for manufacturing of cutlery. Another cause for the localisation of production has been the support of a court. In the Middle Ages many rulers in Europe constantly changed their residences (partly for sanitary reasons). They frequently invited artisans from a distance and settled them in a group near the royal court. Once the court left, if the town survived, it continued the development of a specialised industry in many cases (Marshall, 1890, p. 329-30).

There is a view, on the one hand, that cities started growing around royal courts and bishops' seas (concentration of consumers). Later on, the administrative, defence and educational dimension of towns and cities reinforced their function as consumers, but industrial production also started evolving in the cities. Today, many cities produce more value added than they consume.

On the other hand, there is also an observation that "clusters often emerge and begin to grow naturally. Government policy had little to do with the beginning of Silicon Valley or the concentration of mechanical firms around Modena, Italy. Once a cluster begins to form, however, government at all levels can play a role in reinforcing it. Perhaps the most beneficial way is through investments to create specialized factors, such as university technical institutes, training centres, data banks, and specialized infrastructure' (Porter, 1990, p. 655). In fact, many governments impede the development of clusters and subsidise firms to locate in the area without supporting infrastructure. It does not come as a surprise that firms located in such areas demand subsidies to continue operations in the future. However, universities have always been established in cities. Children and students had to be assembled. Only relatively recently universities did become established in the countryside.

Governments and big TNCs often have nothing to do with the establishment of clusters (Silicon Valley, clusters in Italy, City of London financial district), but may easily support their growth through the provision of education, infrastructure, tax policy, ${ }^{22}$ as well as through sponsoring of research and development (R\&D).

\footnotetext{
${ }^{22} \mathrm{~A}$ limited survey reveals that fiscal variables matter little regarding business location. However, business executives often lobby hard for fiscal incentives. One can understand that as firms have no incentives to forego such direct and indirect subsidies, even if they do not affect location decisions to a significant degree (Wasylenko, 1991). High quality infrastructure is preferred by foreign investors to tax incentives. Transfer pricing and tax deductions in the home country provide other ways to minimise the tax burden on profit (Wheeler and Mody, 1992, pp. 71-2).
} 
Fund-hungry governments can increase taxes on firms in a cluster (up to a certain extent) without provoking a flight of firms from the cluster. However, such policies may be unfriendly to future investment and the development of the cluster.

Firms cluster together in order to benefit, among other reasons, from the availability of a close network of suppliers. They usually group together in locations with large local demand. This demand will be large in the areas where most producers chose to locate (a process of circular interdependence or cumulative causation). 'There is a degree of indeterminacy in the location of activities - firms locate where they do because of the presence of other firms, not because of underlying characteristics of the location' (Venables, 1996, p. 57). ${ }^{23}$ For example, there are around 600 tanneries in Arzignano (Vicenza, Italy), most of which employ just a few dozen workers. The region, however, produces 40 per cent of Europe's leather supply. The area around Vicenza does not only soak, dye, stretch, stamp, cut and ship material used for Gucci handbags, Louis Vuitton luggage, Nike sneakers and BMW car seats, it also produces gold chains, clothing and machine tools, many of them for export. The major problem of a small or a mediumsized enterprise is often not in its 'smallness', but rather in its isolation. Clustering may overcome this problem. Papageorgiou (1979) demonstrated that agglomerated firms can achieve higher aggregate profit, lower prices per unit of output and face greater demand than more dispersed firms.

Should one in such an indeterminate situation regarding the location of firms search for answers to the questions of the geography of production elsewhere? Should it be outside economics? Should it be in non-linear dynamics (popularly known as 'chaos theory'), which examines unstable behaviour with multiple dynamic equilibria, bifurcations and extreme sensitivity to initial conditions; or in self-organisation (spontaneous appearance of order) ${ }^{24}$ so common in complex systems; or in evolutionary biology (evolution and hybridisation); or elsewhere? 'Organisms are vulnerable, but they are not passive; they dig holes, build dams, modify the environment, and create their own niches of survival. Thus organisms and their environment interact, and together they form an ecological system that is better treated as a whole' (Auyang, 1998, p. 61). Similarly, the effects of exter-

\footnotetext{
${ }^{23}$ Japanese business firms operating in Germany have an unexplainable attraction to Dusseldorf rather than Frankfurt' (Beckmann, 1999, p. 61).

${ }^{24}$ Do you remember when the audience applauds after an opera? After a brief period of time, it will all of a sudden start clapping at the same tempo without any conductor. Such self-organisation happens when many initially uncorrelated actions lock into each other's rhythm and create a strong collective group.
} 
nalisation are also pronounced in economics. Consumers' tastes, private and public institutions interact, evolve and alter over time. Consumers, for example, in similar situations make different choices (recall the diversity of breakfast cereals, painkillers, cigarettes, chocolate bars, T-shirts, shoes, cars or bicycles). Hence, complex systems keep on moving from one pseudo-stable situation to another.

A river may over centuries harden its bed and reinforce the work of natural forces over time. However, a strong earthquake (a bifurcation point) may instantaneously change such a long history. That was the case with the mechanical cash registers that were made obsolete by digital ones. Subsequently, optical scanners that read bar codes replaced digital cash registers. Those changes were all based on totally different technologies. Other examples may be found in the almost overnight disappearance of the market for film cameras after the appearance of video cameras; redressing of the market for mechanical watches after the invention of digital and quartz ones; a shift from dot matrix to laser printers; or fibre optics that evolved independently of the telecommunication technology. Firms such as Microsoft or Intel continuously make competence enhancing investments that make their own products obsolete. A good encyclopaedia has always been a must if parents want their children well educated. A door-to-door salesman of Encyclopaedia Britannica has been replaced by Microsoft's cheap CD-ROM encyclopaedia Encarta produced first in 1993. In addition, Amazon is taking business from real world retail booksellers. No single source of advantage appears to last for very long. Even unique raw materials can be replaced by synthetic substitutes. Innovation is threatening firms from every side even from within; hence being a key player is not a state, but rather a process. Hence, one needs to recall one of the main lessons from the two century long growth theory: it is innovation, rather than capital accumulation that is the real source of growth in the long term.

The principal key of success in clusters of related firms in northern Italy ('Padania') is their ultra specialisation and family-run type of business. Relatives support each other in business so there is no need for supervision, they relentlessly upgrade skills and they have opportunities for invention. Common values and local consensus is preserved. This reduces the possibility for business sclerosis, so common in large, vertically organised firms. For example, in Lumezzane (near Brescia) which produces two thirds of the national output of bottle openers: one family is strictly specialised in the production of screws, another has expertise in covers, etc. A similar situation exists in Cadore (near Austria) with the production 
of spectacles. In general, company strategy is friendly with fast changes, customised products and niche marketing. Clusters or industrial districts differ in their origin, business structure, institutional and social organisation, as well as in the scale of public intervention. None the less, one may find certain properties in such industrial districts. They include (Garofoli, 1991a, p. 52):

- A high level of division of labour and between the firms and close input output relations;

- A high level of specialisation which stimulates accumulation of knowledge and introduction of new technologies;

- A high level of skills of workers as a result of a very long term accumulation of knowledge at a local level;

- A large number of local competitors which leads to the adoption of 'trial and error' behaviour and fast imitation by others;

- Efficient local informal (and formal) system for the exchange of information; and an increased importance of face to face relationship.

In addition, there also need to be present:

- Entrepreneurs;

- Innovators;

- Financial institutions with venture capital; and

- Demanding clients.

In spite of a few global TV stations such as the BBC or CNN and newspapers such as The International Herald Tribune or electronic media, one may find that most of the stories that editors still publish or broadcast are local. Proximity of firms in the same industry increases both the visibility of the course of action of competitors and the speed of the spread of information. 'Popular luncheon spots are patronized by executives from several companies, who eye each other and trade the latest gossip. Information flows with enormous speed' (Porter, 1990, p. 120). This 'cafeteria effect' breaks the geographical boundaries to information flow and gives incentives for the creation of matching improvements by other firms in the cluster. It also offers a partial confirmation that there is a spatial limit to knowledge spillovers.

The high speed of the diffusion of information is one of the major strengths of 
clusters. Entrepreneurs often prefer to enter or stay in a cluster even though elsewhere they may be able to achieve a higher return on their innovation. The reason for the preference to stay in the cluster is that the firms there are not only providers of information, but also recipients (Schmitz, 1999, p. 475). In the fields where technology changes often, personal contact may be a preferred way of communication than the less timely sources such as professional journals, fairs and conferences. 'Human capital accumulation is a social activity, involving groups of people in a way that has no counterpart in the accumulation of physical capital' (Lucas, 1988, p. 19). This all supports progress in technology (creation of knowledge).

Personal contacts and informality are essential for the exchange of tacit knowledge. 'Tacit knowledge, as opposed to information, ... can only be transmitted informally, and typically demands direct and repeated contact. The role of tacit knowledge ... is presumably the greatest during the early stages of the industry life cycle, before product standards have been established and a dominant design has emerged' (Audretsch, 1998, p. 23). 'Companies that have gone furthest towards linking their global operations electronically report an increase, not a decline in the face-to-face contact needed to keep the firms running well: with old methods of command in ruins, the social glue of personal relations matters more than ever' (The Economist, 30 July 1994, p. 11). Such a durable social network, informality in contacts and local embeddedness are essential for identifying user requirements, proper installation, operation and service of the product. ${ }^{25}$

The growing importance of intangible assets, particularly intellectual capital, increases the importance of knowledge externalities (spillovers) and frequent faceto-face contacts among the relevant players. They need to exchange uncodifiable knowledge, to involve in interactive learning, have feedback and suggestions, as well as have a dialogue about risk and the changing situation in the market and technology. 'Knowledge is the most important resource and learning is the most important process' (Pinch and Henry, 1999, p. 820). Knowledge externalities are one of the key reasons for the existence and success of clusters. Hence, clusters may also be seen as networks for information gathering, facts processing and a network of production places. "Almost every internationally successful Italian industry has several if not hundreds of domestic competitors. Frequently, they are

\footnotetext{
${ }^{25}$ Personal contacts, proximity and trust of a partner are emphasised by Gordon and McCann (2000, p. 520), Sternberg and Tamasy (1999, p. 374), Porter and Solvell (1998, pp. 445-6) and Kleinknecht and ter Wengel (1998, pp. 645-6), but were well known also to Perroux (1955, p. 317 and 1961, p. 152).
} 
all located in one or two towns. ... Where domestic rivalry is absent Italian firms rarely succeed internationally' (Porter, 1990, p. 447).

The existence of competitors in the vicinity serves a useful business and social purpose. If one imagines a cluster in the shape of an input-output matrix for information, then the direct and indirect functional relations are 'diffused' through rows and columns. Competition increases productivity which is the key ingredient of prosperity. Firms do not chase every chance to ruin rivals. This is contrary to the standard story in every introductory economic textbook. ${ }^{26}$ Every firm in a cluster perceives its survival, growth and success in terms of collective growth. These firms learn and prosper collectively. The learning process in a cluster is not only interactive, but also cumulative as it persists over time (once it exists it does not cease to exist, experience and discovery builds on experience and discovery). Turnover of labour, technical staff and management among these firms reinforces the transfer of tacit knowledge, cross-fertilising research, collective learning processes and regional competitive advantages.

The underlying general operations within a cluster can be seen from another example. 'New York City's garment district, financial district, diamond district, advertising district and many more are as much intellectual centers as is Columbia or New York University. The specific ideas exchanged in these centers differ, of course, from those exchanged in academic circles, but the process is much the same. To an outsider, it even looks the same: A collection of people in similar activities, each emphasizing his own originality and uniqueness' (Lucas, 1988, p. 38). Continuous and straight dealings among players can pass on and exchange tacit and accumulated knowledge among players. Social closeness in such cases may be equally, if not more, relevant than geographical proximity. However, established locations can be vulnerable to 'technological lock-in' in certain cases. Some regions become victims of their own success because they became complacent and lose their competitive and innovative capacity. For example, the German Ruhr region was lead into the 'trap of rigid specialisation' (Grabher, 1993, p. 275). New ideas may need new space. 'When IBM developed its own personal computer, the company located its fledgling PC capacity in Boca Ratton, Florida, way outside of the manufacturing agglomeration in the North-east Corridor' (Audretsch, 1998, p. 24). This is an example of a bifurcation point.

\footnotetext{
${ }^{26}$ Even though Siemens is a dominant firm in the Munich high technology cluster, it does not threaten or absorb SMEs in the cluster, but rather develops ties with SMEs that are characterised by collaboration (Sternberg and Tamasy, 1999, p. 375).
} 
The old industrial regions in advanced countries exhibited relatively long periods of growth. They were highly specialised in products that serve as basic inputs (coal, steel and chemicals) in the production of other goods or in the manufacture of goods for mass consumption (clothing or cars). However, competition from relatively low-labour cost Asian countries contributed to the economic decline of such clusters in the western countries from the 1970s. According to a dated model this process may find a parallel in the life cycle of a product. A more modern 'network' explanation adds to the economic aspects of over-specialisation a sociocultural and institutional dimension to explain the meagre ability of old industrial clusters to learn, innovate, apply, absorb, spread and adjust to new realities (Boschma and Lambooy, 1999a).

Technological, institutional and political lock-in in old agglomerations places the region in rigid trajectories. This path dependency, routine, a narrow focus on a specific activity and cosy relations between public authorities, business community and labour unions which safeguard the current structure, may often prevent the region from adjusting to new technologies and changes in demand, tastes and market situation. It is still not clear if dealing with such a situation calls for local institutional 'thickness' or 'thinness' in order to revive the local economy. There are at least two ways to address this problem:

- The neo-classical policy advice on this situation would be to enhance factor mobility.

- The evolutionary approach to counter this situation would be to increase local networking, learning and innovative capacity, to reduce dependence on various local 'lock-ins' and to stimulate new start-ups.

Even though there is a certain pessimism regarding the large-scale revival of old industrial clusters, it is often overlooked that new footloose industries do not need to establish ex ante local linkages in order to develop. They often rely to a large extent on their own skills to create conditions for growth. For example, new environment-related industries are emerging in the Ruhr (the connection may be the solution of the pollution problem). In addition, there is little technological continuity between the textile machinery complex in New England of the $19^{\text {th }}$ century and the current electronics cluster (Boschma and Lambooy, 1999a). 


\section{B. War and Location of Firms}

Unexpected political events (chances, accidents) such as wars can not be predicted by everyone with a high degree of certitude. Nonetheless, wars decisively influence development, expansion, location, dislocation and spread of certain industries. There are numerous examples that support such arguments. For instance, as a late comer in the colonial era and because of post war(s) external sanctions, Germany had the 'incentives' (was forced by events) to produce various chemicals as substitutes for natural inputs that were not available either in colonies or through 'normal' trade. Self-sufficiency has often been of vital national importance. Germany's success was remarkable as the country developed world-leading chemical and related industries such as pumps, sophisticated precision measurement and control instruments. Let us consider other examples.

- There was a recession in Seattle (Washington) after the First World War. The economy of the region was based on fishing, production of timber and ship/ boat building. At about the same time demand for aircraft (made of wood) started to emerge. There were unemployed boat-builders and other inputs. Workers had talents in making wooden boats, they could easily make a fully covered boat (the body of an aeroplane), they also knew how to fix a propeller, which lead to the emergence of Boeing. The U.S. was the country that took advantage of airmail on a large scale, large purchases of military aircraft and large demand for fast travel, which in turn provided domestic producers with early incentives to lower production and learning costs per aircraft as compared with foreign competitors.

- The first commercially successful motor scooter, the Vespa, was produced by the Italian company Piaggio in 1946, although the idea for it was conceived during the Second World War. ${ }^{27}$ During the war, Piaggio, at Pontandera, near Pisa, made aircraft engines. After RAF bombing destroyed the factories, warehouses and roads at the site, it became difficult and tiring to get around the site on foot. The company owner, Enrico Piaggio, asked one of his engineers, Corradino d'Ascanio to come up with a simple and economical two-wheel personal vehicle. D'Ascanio built the prototype using his imagination, the

\footnotetext{
${ }^{27}$ The first of many attempts to produce a small, economical runaround vehicle early in the 20th century resulted in the Auto-Ped. Introduced in New York in 1915, this looked like a child's scooter: it had no seat and a platform for the rider to stand on. A two-horsepower motor gave the Auto-Ped a maximum speed of $55 \mathrm{~km} / \mathrm{h}$.
} 
leftovers from small two-tact motors used to start the aircraft engines, aircraft wheels (note the shape of wheels on a Vespa when you next see one) and whatever else he could find in the warehouse (or what remained from it), such as metal sheets. It also incorporated a shield on each side to protect the rider's legs from injury. The prototype was ready within a few weeks and once in production, the Vespa became an immediate hit. It was extremely popular and fashionable in the 1950s and 1960s and was rediscovered by another generation in the 1990s because of increasing traffic congestion in cities.

- The Swiss chemical and heavy industry had certain benefits during the world wars. On the one hand, the German industry did not have access to the international market, hence the Swiss entrepreneurs filled the gap where they could. On the other hand, the Swiss benefited from the inflow of funds, talents and invalidation of German patents by the Allies.

- Caterpillar went from the U.S. abroad during the Second World War in order to service machines that were used by the U.S. Army. Following the War, the machinery that remained abroad had to be serviced. Hence, Caterpillar became an international company on a larger scale. Coca-Cola also followed the U.S. Army during the Second World War to keep up the morale of the soldiers, and also remained abroad after it. Mars Bars were also distributed to armed forces all around the world during the War. ${ }^{28}$

- Sialkot is a provincial town in the Punjab, Pakistan. It had a military garrison and a mission hospital during the British period a century ago. This created a demand for repair and, later on, production of surgical instruments, tennis rackets and footballs. The area had had a local tradition of producing swords and daggers for several centuries. When the military technology changed, the need for surgical instruments from the local hospital provided demand for sharp scalpels. Later on, around the Second World War, the supply of surgical instruments was necessary for the war efforts. Technology and experts were brought from Britain in order to support the production of those goods. Currently, a core of around 300 family-run firms (almost all have less than 20 employees) in Sialkot produce a range of 2,000 surgical instruments. They are, together with firms in Germany, major world exporters of surgical instruments. As Sialkot has no airport and as it is located over 1,500 km from the

\footnotetext{
${ }^{28}$ In an attempt to eliminate the textile waste during the Second World War, the U.S. government reduced by one-tenth the amount of fabric allowed for women's swimwear. The chain of events that resulted in the ever decreasing amount of material necessary for the bikini was set in motion.
} 
nearest sea port, a private self-help action created the Sialkot Dry Port Trust which brought 'the port to Sialkot'. The Trust offers a range of collective services such as customs clearance, warehousing and transport. The success of this, as well as all other clusters is based on two factors. First, the demand driven approach and, second, competition based on collective efficiency. However, not all is ideal in Sialkot. Infrastructure is still rather undeveloped. Power supply is inadequate, communications are poor and roads are covered with ankle deep mud during the monsoon season. Health and safety standards are insufficient and child labour is a serious problem in Sialkot's football making industry (Nadvi, 1998).

- Italian motor car racing companies such as Alfa Romeo, Ferrari and Lancia dominated the market in the period immediately after the Second World War. Within several years, however, a cluster of small firms from around Oxford became another dominant world player. There were several fortuitous events that prompted this evolution. First, there was a huge surplus of abandoned airfields in southern England after the War. Second, Mercedes withdrew from motor racing in 1955 after an accident in Le Mans in which 183 spectators were either killed or injured. This left room for the British racing car builders. Third, large and vertically integrated manufacturers such as Ferrari and Porsche built cars for their own racing teams, while the British were selling cars to everyone that wanted to buy them. Even though the British were not winning races, they dominated the staring grids with the number of cars. Fourth was the ban on cigarette advertising on TV in Britain in 1965. Tobacco companies became sponsors of motor racing with vast sums of money in return for having their logos on the racing cars. Pinch and Henry (1999) argue that although the success of the British constructors may have been influenced by a few accidents, it was only to a small extent. Other more important causes such as accumulated knowledge, its circulation through the companies by the means of transfer of personnel, as well as skilled labour, are the origins of the British success. The British have a tradition of expertise in engines and lubricants, aerodynamics and composite materials. In particular, the national aerospace industry was bigger and more sophisticated after the War than the one in Italy. This could, according to Pinch and Henry, probably have encouraged the production of racing cars even without the Mercedes crash and without the money from cigarette manufacturers. 


\section{Clusters}

A cluster is a large group (a critical mass) and a system of functionally related firms, knowledge, skills and specialised institutions in a particular geographical location. This functional relation among the firms may be downstream (suppliers), horizontal (competitors and collaborators), upstream (clients) and/or through the circulation of the accumulated knowledge and skills by the means of turnover of personnel.

A concentration of functionally related business activities within a relatively small area (agglomeration; 'thick' market effects; benefits of co-location; and non-ergodicity $^{29}$ ) provides firms with collective gains that would not be available if the firms operated in a remote place. These shared benefits or externalities are different from the ones that are created within and available to a single firm. In essence, clusters create economies that are external to individual firms, but internal to a network of firms in a cluster. Hence, a great deal of an individual firm's competitive advantage is outside it, but inside the location where it operates.

A firm locates in an area where there are firms from the same or related industry (in a cluster) because:

- it has production links with other firms;

- it may benefit from the already existing pool of suppliers;

- there are services such as finance, information, consulting and maintenance;

- there may be a pool of trained and experienced labour;

- firms may reduce the cost of transport;

- there may be a concentration of consumers (proximity to the major growing markets is often the most important reason for the selection of a particular location); and

- they may jointly negotiate contracts with transporters and organise export promotion or marketing boards and the like.

The production geography of the U.S. is particularly interesting as it is a country

\footnotetext{
${ }^{29}$ An ergodic system (a pendulum) returns at the end to its original state no matter what the disturbances between the starting and ending points in time.

${ }^{30}$ One has to be careful regarding comparisons between the current, post World War II European integration and the evolution of integration in the US. To integrate the country, the American Civil War (1861-65) took the lives of 620,000 persons in a nation of 35 million. (This loss would be comparable to a loss of 6.7 million people in the $E U$ of 2002.) More persons died of disease and sickness than on the battlefield; the ratio was about $4: 1$.
} 
without important internal borders and it is so big that it may serve as an example for economic comparison with an integrated Europe. ${ }^{30}$ Even a superficial look at U.S. production geography reveals a high concentration of industries. The implication is that the U.S. clusters profit from large scale production for an almost homogenised large national market. For example, the following industrial clusters come to mind:

- aviation around Seattle

- finance on Wall Street

- insurance in Hartford (Connecticut)

- electronics in Silicon Valley and Boston's Route 128

- advertising on Madison Avenue in New York City

- diamonds on the $47^{\text {th }}$ street in New York City

- optics related industries in Rochester (New York)

- cars around Detroit

- medical equipment in Minneapolis

- paints and coatings in Cleveland (Ohio)

- entertainment in California

- office furniture in western Michigan

- orthopaedic devices in Warsaw (Indiana)

- hosiery and home furnishings in North Carolina

- carpets in Dalton (Georgia)

- wine in Napa Valley (California)

- gambling in Las Vegas and Atlantic City

In Europe, production of knives is clustered in Solingen, watches in Geneva and the Swiss Jura, financial services in London, fashion garments and motorcycles in northern Italy, pleasure in Paris, flowers in Holland, sex/prostitution ${ }^{31}$ in Amsterdam, carpets in Kortrijk (Belgium), but the European car industry has never created a cluster similar to Detroit.

Italy is an often quoted example of a country with distinct manufacturing clusters. A select group of those clusters include the following: ${ }^{32}$

\footnotetext{
${ }^{31}$ This has always been an urban 'activity' because cities 'sell' anonymity and tolerance.

${ }^{32}$ The list is based on data for 1996; if available the number of related firms in the cluster is given in square brackets; and a bigger city in the vicinity or province is given in 'normal' brackets. Source: "Quanti sono i distretti industriali in Italia?", Newsletter Club dei Distretti Industriali $\mathrm{n}^{\circ}$ 9, Novembre 1998, Club dei distretti industriali Prato, p. 9.
} 
- motorcycles in Bologna [2,370]

- electronics, mainly alarms for cars in Varese [100]

- jewellery in Valenza Po [1,400] (Alessandria); Vicenza [1,100]; Arezzo [1,300] (Florence)

- spectacles in Cadore [930] (Belluno)

- textiles and clothing in Sempione [3,900] (Varese)

- textiles around lake Como; Prato [8,481] (Florence); Olgiatese [2,614] (Varese); Biella [1,300] (Piedmont); Valdagno (Pisa)

- clothing in Val Vibrata [1,150] (Pescara); Empoli (Florence); Treviso

- female underwear in Castel Goffredo [280] (Mantova)

- silk in Comasco [2,600] (Como)

- wool in Biella

- knitwear in Carpi [2,054] (Modena)

- shoes in Fermo, Montegranaro, Porto Santelpidio, Sanbenedetto, San Benedetto del Trono (Ancona); Lucca, Santa Croce Sull'Arno [1,749] (Pisa); Ascoli [3,100]; Riviera del Brenta [886] (Padova)

- sports footwear in Montebelluna [623] (Treviso); Asolo (Treviso);

- tannery in Arzignano [600] (Vicenza) and Solofra (Naples)

- ceramic tiles in Sassuolo [199] (Bologna)

- marble in Apuo-Versiliese [1,161] (Carrara)

- taps and valves in Alto Cusio [300] (Novara)

- furniture in Brianza Comasca Milanese [6,500] (Milan); Cantù [7,200] (Milan); Alto Livenza [2,000] (Udine); Poggibonsi [1,294] (Siena); BovoloneCerea [3,000] (Verona)

- kitchens in Pesaro [1,200]

- chairs and tables in Udine [1,200]

- wood machinery in Rimini [1,345]

- agricultural machinery in Modena [100]

- foodstuffs in Parma [215]

- saucepans and valves in Lumezzane [1,008] (Brescia)

- packaging machinery in Bologna

- musical instruments in Castelfidardo [400] (Ancona)

Clusters in Germany:

- steel in Dortmund, Essen and Düsseldorf 
- locksmith's products in Velbert

- cutlery in Solingen

- surgical instruments in Tuttlingen

- chemicals in Leverkusen, Frankfurt and Ludwigshafen

- jewellery in Pforzheim

- cars in Wolfsburg, Stuttgart, Munich, Ingolstadt, Neckarsulm and Regensburg

- machine tools in Stuttgart

- pens and pencils in Nuremberg

- printing presses in Heidelberg, Würzburg and Offenbach

- optics in Wetzlar

- tool-making in Remscheid

Once the concentration of business becomes too high, there may be negative externalities for work and private life such as pollution, sewage and waste disposal problems, congestion, crime and an increase in the price of land and rents. This may have an impact on the spread and decentralisation of businesses and their shift to other regions as firms may wish to leave the 'threatened' regions. However, the $E U$ has on the average a much less concentrated manufacturing geography and much more segmented markets than the U.S. because of various non-tariff barriers which increase trade costs. The goal of the Single Market Programme (1985-92) was to eliminate all technical and administrative barriers on internal trade. Hence, if this takes place, the expectation was that $E U$ industries and its geography of production may resemble, to an extent, the ones in the U.S. One should not go as far as to think that the $E U$ will ever have such a homogeneous market as the U.S. Most of the things and the way of doing things (culture) in the U.S. are alike throughout the country (e.g., food, habits, services, how towns and villages look). In the $E U$, for instance, citizens have distinct national and strong regional consumer pref-erences for food and drink. This will persist. In addition, the $E U$ countries have a range of national policies regarding health, safety, social issues and worker representation.

A lesson for the $E U$ is that the 1985-92 Single Market Programme (integration deepening) provided certain opportunities for a concentration of production in select hot spots, as well as for rationalisation of business operations. Amiti (1998, 1999) found certain evidence that this took place in the manufacturing industries which include industrial chemicals, petroleum, textiles, plastics, iron and steel, machinery and transport equipment. These are all industries that are subject to 
economies of scale and that have a high proportion of intermediate inputs in final production. Hence, this provides certain support to the arguments of the new theory of spatial economics. In the period 1976-89 geographical concentration increased in 30 out of 65 recorded industries, concentration fell in 12 industries (the biggest fall was in the manufacturing of concrete for construction), while there was no significant change in the geographical concentration in other industries (Amiti, 1999, p. 580). Midelfart-Knarvik et al. (2000) found that 'between 1970/73 and 1994/97, the general trend towards spatial dispersion is reflected in 29 out of 36 industries' (p. 30) and that there is an 'impression of a spreading out of European manufacturing activity' (p. 30). On the other hand, a study by the European Commission observes that an 'examination of data offers mixed evidence for the contention that the single market is leading to a geographical concentration' (p. 67) and that there is 'little evidence of concentration occurring in the EC' (European Commission, 1998, p. 69). Hence, this topic calls for further research.

Fragmentation of markets in individual $E U$ countries had as its result a replication of various output functions. The primary impact of the Single European Market on TNCs located in the $E U$ was through increased competition. TNCs were led to coordinate production in their subsidiaries in order to profit from economies of scale. Horizontally integrated TNCs such as $3 \mathrm{M}$ responded to the deepening of integration in the $E U$ by specialisation of production in their plants. 'Post it' notes are made in its British plant, while scotch tape is produced in its German unit. Previously, 3M produced a wide range of 'sticky' goods in each country in order to serve predominantly the local market. Vertically integrated TNCs such as Ford responded to the new opportunities by vertical specialisation. Differentials and gearboxes are produced in France, while engines are made in Spain. A further restructuring of the company, announced in 2000, ended production in Belarus, Poland and Portugal, and concentrated output in Germany, Spain and Belgium. ${ }^{33}$ In addition, there emerged a special kind of relation among the competing firms. A removal of non-tariff barriers on internal trade and liberalisa-tion of public procurement 'forced' inter-firm specialisation in similar goods. For example, ICI (Britain) specialised in marine, decorative and industrial paints, while BASF (Germany) did the same in automobile paints (Dunning, 1994, pp. 296-7).

In spite of the potential for the concentration of production that was provided by

\footnotetext{
${ }^{33}$ The Financial Times, 13 May 2000, p. 1.
} 
the Single European Market, the Japanese (and the U.S.) car-producing TNCs continue to spread locations for production in the $E U$, rather than simply aim to concentrate production to employ economies of scale (Ando, 1998, p. 23). Although the Japanese started assembling cars in Britain, they are now settling their new production activities elsewhere in the $E U$ (Toyota plant in France).

The vast majority of $E U$ countries 'experienced a growing difference between their industrial structure and that of their EU partners' (Midelfart-Knarvik et al., 2000 , p. 9). These growing divergences in the geography of national production may be the consequence of two factors. One comes from the importance of history. This is when countries initially have industries that grow at different rates. Hence, a country with a higher proportion of high growth industries becomes increasingly more specialised than the average or the rest of the group. The other factor is the 'differential change'. This is when countries move out of a certain type of production and into another. Midelfart-Knarvik et al. $(2000$, p. 6) found that over 80 per cent of the change in the $E U$ during 1980-97 was due to the 'differential change', while the rest came from the amplification of the initial differences. The most striking feature of this process was a change in the industrial structure of Ireland and Finland. New high technology industries and the ones subject to increasing returns to scale were located in these two countries.

\section{Conclusion}

In the age of 'globalisation' of business, one expects ex ante the importance of a specific location for a firm or an industry to diminish. Some argue that 'distance is dead'. However, local proximity (clusters) of firms that produce similar, competing and/or related products, together with supporting institutions and accumulated knowledge and skills, still matters. Economies of scale, activityspecific backward and forward linkages (indivisible production), accumulated knowledge, innovation, existence of sophisticated customers and a fall in transportation costs play relevant roles in the 'protection' of clusters and absolute advantages of certain locations. 'Global' competitiveness often depends on highly concentrated 'local' knowledge, skills, capabilities and a common tacit code of behaviour which can be found in a geographical concentration (a cluster) of firms.

Accumulated tacit knowledge and experience that can not be codified, copied or easily transferred at arm's length to other rivals, still keeps most of the competitive strength at a local level in spite of the large talk of 'globalisation'. The local/ 
regional authorities can influence, reinforce, recover and improve the efficient use of own economic resources and capabilities. This energy is based on the fact that there is a strong, collective and accumulated learning process at the local level.

Availability of highly skilled and educated workers is becoming an increasingly important determinant for industrial location. This is reinforced by the limited spatial spillovers of knowledge, hence in certain industries 'local' clusters matter for the 'global' competitiveness of firms. National economic policies concerning investment, industrial change, $\mathrm{R} \& \mathrm{D}$, mobility of people, skills and knowledge, investment in human capital (education) that develops and extends skills, experience and organisational competencies is crucial for the efficiency of the economy. Regional and social affairs also play a role as sometimes regional and social policies impede the development of clusters on behalf of equity considerations among national regions.

The analysis of spatial economics and global and local settling of firms and industries depends on special assumptions. It is often a study of particular cases. Nonetheless, many useful things can be learned from exceptional situations. The examination of the issue is still more suggestive (in particular how a historical accident may shape production geography) than conclusive. A coherent theory of the subject is not yet in sight. However, there are various approaches that contribute to the raising of new questions and understanding of the issue. This leaves the topic subject to further theoretical and empirical analysis. ${ }^{34}$

\section{Acknowledgement}

Je tiens à remercier tout particulièrement Marinette Payot qui m'a beaucoup aidé sans que je le sache. I have benefited from discussions with and intellectual capital of many friends and colleagues, but I owe special gratitude to Lisa Borgatti, Ron Boschma, Gioacchino Garofoli, Birgit Hegge, Jong Eun Lee, Antonio Majocchi, Marina Rossi, Bertram Schefold and two anonymous referees. Christopher Smith edited the text. The views expressed are my own and do not reflect the position of the organisation for which I work.

Received 7 July 2001, Accepted 15 February 2002

\footnotetext{
${ }^{34}$ Public policy and administrative areas in which the authorities collect statistics are usually not equal to clusters. That is the reason why it is hard to determine the exact economic significance of clusters with a high degree of reliability.
} 


\section{References}

Amiti, M. (1998), "New trade theories and industrial location in the $E U$ : a survey of evidence", Oxford Economic Papers, pp. 45-53.

Amiti, M. (1999), "Specialization patterns in Europe", Weltwirtschaftliches Archiv, pp. 573-593.

Ando, K. (1998), "The Single European Market and the location strategy of foreign car multinationals", Discussion Paper No. 249, University of Reading, Department of Economics.

Arthur, B. (1989), "Competing technologies, increasing returns, and lock-in by historical events", Economic Journal, pp. 116-131.

Arthur, B. (1990), "Positive feedbacks in the economy", Scientific American (February), pp. 92-99.

Arthur, B. (1990a), "Silicon Valley locational clusters: when do increasing returns imply monopoly", Mathematical Social Sciences, pp. 235-251.

Arthur, B. (1994a), "Industrial location patterns and the importance of history", in Increasing Returns and Path Dependence in the Economy (ed. B. Arthur). Michigan: University of Michigan Press, pp. 49-67.

Arthur, B. (1994b), "Urban systems and historical path dependence", in Increasing Returns and Path Dependence in the Economy (ed. B. Arthur). Michigan: Michigan University Press, pp. 99-110.

Audretsch, D. (1998), "Agglomeration and the location of innovative activity", Oxford Review of Economic Policy, pp. 18-29.

Auyang, S. (1998), Foundations of Complex-system Theories in Economics, Evolutionary Biology and Statistical Physics. Cambridge: Cambridge University Press.

Bair, J. and G. Gereffi (2001), "Local clusters in global chains: the causes and consequences of export dynamism in Torreon's blue jeans industry", World Development, pp. 1885-1903.

Beckmann, M. (1999), Lectures on Location Theory. Berlin: Springer.

Bernstein, J. and D. Weinstein (2002, "Do endowments predict the location of production? Evidence from national and international data", Journal of International Economics, pp. 55-76.

Blackhurst, R. and D. Henderson (1993), "Regional integration arrangements, world integration and GATT", in Regional Integration and the Global Trading System (eds K. Anderson and R. Blackhurst). New York: Harvester Wheatsheaf, pp. 408-435.

Brainard, W. and J. Tobin (1992), "On the internationalization of portfolios", Oxford Economic Papers, pp. 533-565.

Boschma, R. and J. Lambooy (1999), "The prospects of an adjustment policy based on collective learning in old industrial regions", GeoJournal, pp. 391-399.

Caves, R. (1996), Multinational Enterprise and Economic Analysis. Cambridge: Cambridge University Press. 
Christaller, W. (1933), Die Zentralen Orte in Süddeutschland, Jena: Gustav Fischer. [Translated from German by C. Baskin Central Places in Southern Germany (1966), Englewood Cliffs: Prentice-Hall].

Dunning, J. (1988). Explaining International Production. London: Unwin Hyman.

Dunning, J. (1994), "MNE activity: comparing the NAFTA and the European Community", in Multinationals in North America (ed. L. Eden). Calgary: University of Calgary Press, pp. 277-308.

Dunning, J. (1999), "The eclectic paradigm as an envelope for economic and business theories of MNE activity”, Discussion Paper No. 263, Department of Economics, University of Reading.

Eaton, C. and R. Lipsey (1976), "The non-uniqueness of equilibrium in the Löschian location model", American Economic Review, pp. 77-93.

Eaton, C. and R. Lipsey (1997), On the Foundations of Monopolistic Competition and Economic Geography. Cheltenham: Edward Elgar.

European Commission (1998). Foreign Direct Investment. London: Kogan Page.

Fujita, M., P. Krugman and A. Venables (1999), The Spatial Economy. Cambridge: MIT Press.

Garofoli, G. (1991), "Industrial districts: structure and transformation", in Endogenous Development and Southern Europe (ed. G. Garofoli). Aldershot: Avebury, pp. 49-60.

Gordon, I. and P. McCann (2000), "Industrial clusters: complexes, agglomeration and/or social networks?", Urban Studies, pp. 513-532.

Grabher, G. (1993), "The weakness of strong ties: the lock-in of regional development in the Ruhr area", in The Embedded Firm (ed. G. Grabher). London: Routledge, pp. 255277.

Graham, E. (1978), “Transatlantic investment by multinational firms: a rivalistic phenomenon?", Journal of Post Keynesian Economics, pp. 82-99.

Henderson, J. (1974), “The sizes and types of cities", American Economic Review, pp. 640-656.

Hymer, S., (1976), The International Operations of National Firms: A Study of Direct Foreign Investment. Boston: MIT Press.

Isard, W. (1954), "Location theory and trade theory: short run analysis", Quarterly Journal of Economics, pp. 305-320.

Jovanović, M. (2001), Geography of Production and Economic Integration. London: Routledge.

Kleinknecht, A. and J. ter Wengel (1998), "The myth of economic globalisation", Cambridge Journal of Economics, pp. 637-647.

Knickerboker, F. (1973), Oligopolistic Reaction and Multinational Enterprise. Boston: Harvard University.

Kravis, I. and R. Lipsey (1982), "The location of overseas production and production for export by U.S. multinational firms", Journal of International Economics, pp. 201-223.

Krugman, P. (1990), Rethinking International Trade. Cambridge MA: The MIT Press.

Krugman, P. (1991), "History versus expectations", Quarterly Journal of Economics, pp. 
651-667.

Krugman, P. (1992), Geography and Trade. Cambridge MA: The MIT Press.

Krugman, P. (1993), "On the number and location of cities", European Economic Review, pp. 293-298.

Krugman, P. (1998), "What's new about the new economic geography", Oxford Review of Economic Policy, pp. 7-17.

Leamer, E. and J. Levinsohn (1995), "International trade theory: the evidence", in Handbook of International Economics (eds G. Grossman and K. Rogoff). Amsterdam: Elsevier, pp. 1339-1394.

Linder, S. (1961), An Essay on Trade and Transformation. Uppsala: Almquist \& Wiksells.

Lösch, A. (1940), Die Räumliche Ordnung der Wirtschaft, Jena: Gustav Fischer [Translated from German by W. Woglom and W. Stolper, The Economics of Location (1973), New Haven: Yale University Press].

Lucas, R. (1988), "On the mechanics of economic development", Journal of Monetary Economics, pp. 3-42.

Marshall, A. (1890), Principles of Economics. London: Macmillan.

Midelfart-Knarvik, K., H. Overman, S. Redding and A. Venables (2000), "The location of European industry", Economic Papers, No. 142, European Commission.

Moses, L. (1958), "Location and the theory of production”, Quarterly Journal of Economics, pp. 259-272.

Nadvi, K. (1998), "International competitiveness and small firm clusters-evidence from Pakistan”, Small Enterprise Development, pp. 12-24.

Ohlin, B. (1933), Interregional and International Trade. Cambridge: Harvard University Press.

Papageorgiou, G. (1979), “Agglomeration”, Regional Science and Urban Economics, pp. 41-59.

Perroux, F. (1950), "Economic space: theory and applications", Quarterly Journal of Economics, pp. 89-104.

Peroux, F. (1955), "Note sur la notion de, <pôle de croissance>", Économie Appliqué, pp. 307-320.

Perroux, F. (1961), L'Économie du XXe Siècle. Paris: Presses Universitaires de France.

Pinch, S. and N. Henry (1999), "Paul Krugman's geographical economics, industrial clustering and the British motor sport industry", Regional Studies, pp. 815-827.

Porter, M. (1990), The Competitive Advantage of Nations. New York: The Free Press.

Porter, M. and Ö. Sölvell (1998), "The role of geography in the process of innovation and the sustainable competitive advantage of firms", in The Dynamic Firm (eds A. Chandler et al.). Oxford: Oxford University Press, pp. 440-457.

Posner, M. (1961), "International trade and technical change", Oxford Economic Papers, pp. 323-341.

Reuber, G. (1973), Private Foreign Investment in Development. Oxford: Clarendon Press.

Sachs, J. (2000), "Globalization and patterns of economic development", Weltwirtschaftliches Archiv, pp. 579-600. 
Schmitz, H. (1999), "Collective efficiency and increasing returns", Cambridge Journal of Economics, pp. 465-483.

Sternberg, R. and C. Tamásy (1999), "Munich as Germany's no. 1 high technology region: empirical evidence, theoretical explanations and the role of small firm/large firm relations", Regional Studies, pp. 367-377.

UNCTAD (1993). World Investment Report: Transnational Corporations and Integrated International Production. New York: United Nations.

UNCTAD (1997), World Investment Report: Transnational Corporations, Market Structure and Competition Policy. United Nations: New York.

UNCTAD (2000), World Investment Report: Cross-border Mergers and Acquisitions and Development. New York: United Nations.

UNCTAD (2001), World Investment Report: Promoting Linkages. New York: United Nations.

Venables, A. (1996), "Localization of industry and trade performance", Oxford Review of Economic Policy, pp. 52-60.

Vernon, R. (1966), "International investment and international trade in the product cycle", Quarterly Journal of Economics, pp. 190-207.

von Thünen, J. (1826), Der Isolierte Staat in Beziehung auf Landtschaft und Nationalökonomie. Hamburg: Perthes. [Translated from German by C. Wartenberg, von Thüunen's Isolated State (1966), Oxford: Pergamon Press].

Wasylenko, M. (1991), "Empirical evidence on interregional business location decisions and the role of fiscal incentives in economic development", in Industry Location and Public Policy (eds H. Herzog and A. Schlottmann). Knoxville: The University of Tennessee Press, pp. 13-30.

Weber, A. (1909), Über den Standort der Industrien, Tübingen: J.C.B. Mohr [Translated from German by C. Friedrich, Theory of the Location of Industries (1962), Chicago: University of Chicago Press].

Wheeler, D. and A. Mody (1992), "International investment location decisions: the case of U.S. firms", Journal of International Economics, pp. 57-76.

Yamawaki, H. (1993), "Location decisions of Japanese multinational firms in European manufacturing industries", in European Competitiveness (ed. K. Hughes), pp. 11-28. 